\title{
Efficiency of Polychaete Nereis (Neanthes) Succinea as Biomonitor for Heavy Metals Pollution in the Red Sea, Egypt
}

\author{
Rashad El Sayed Mohammed Said ${ }^{1,}$, AbdAllah Tharwat AbdAllah ${ }^{1}$, Mohsen Abdelhafez Mostafa ${ }^{1}$, \\ Nasser Abdellatif El-Shimy ${ }^{2}$
}

${ }^{1}$ Department of Zoology, Faculty of Science, Al Azhar University, Assiut Branch, Egypt

${ }^{2}$ Department of Zoology, Faculty of Science, Assiut University, Assiut, Egypt

Email address:

banjawy@yahoo.com (R. E. S. M. Said)

${ }^{*}$ Corresponding author

\section{To cite this article:}

Rashad El Sayed Mohammed Said, AbdAllah Tharwat AbdAllah, Mohsen Abdelhafez Mostafa, Nasser Abdellatif El-Shimy. Efficiency of Polychaete Nereis (Neanthes) Succinea as Biomonitor for Heavy Metals Pollution in the Red Sea, Egypt. Advances in Bioscience and Bioengineering. Vol. 5, No. 5, 2017, pp. 86-91. doi: 10.11648/j.abb.20170505.13

Received: January 8, 2017; Accepted: January 18, 2017; Published: October 30, 2017

\begin{abstract}
Polychaetes nereids groups are the most common in shallow marine habitats and abundant in benthic communities. This group was proved to tolerate a high burden of heavy metals within their tissues. The current work assesses the effect of water criteria; sea water temperature, hydrogen ion concentration $(\mathrm{pH})$, dissolved oxygen concentration, turbidity, conductivity and salinity on the uptake and storage of four heavy metals; $\mathrm{Mn}, \mathrm{Pb}, \mathrm{Cd}$ and $\mathrm{Cu}$ in tissues of the marine polychaete worm Nereis succinea collected from two sites at Hurghada, Red sea; the Marine Biological Station (MBS) and the Fishing Port at Sakala (FPS). Bioaccumulation Factors (BAFs) were determined to evaluate the capability of the investigated annelid worm to accumulate heavy metals, so as to be used as sentinel species for monitoring metal pollutants. Population density of the investigated polychaete was determined at both studied sites as related to water criteria. ANOVA statistical analysis has indicated significant higher concentration of $\mathrm{Mn}, \mathrm{Pb}, \mathrm{Cd}$ and $\mathrm{Cu}$ in water at FBS than $\mathrm{MBS}(\mathrm{P}<0.01)$ and high tissue concentration of $\mathrm{Mn}, \mathrm{Cd}, \mathrm{Pb}$ and $\mathrm{Cu}$ at individuals collected from FBS $(\mathrm{P}<0.01)$. The highest value of annual mean of

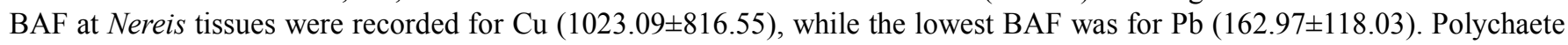
abundance was significantly higher at MBS. Significant effect was found for water criteria on metal bioaccumulation and population density of Nereis. Data were discussed to evaluate the sensitivity of $N$. succinea to heavy metal pollutants and its possible use as biological monitor for metal contaminants at marine habitats.
\end{abstract}

Keywords: Nereis succinea, Heavy Metals, Bioaccumulation, Population Density

\section{Introduction}

Environmental pollution has remarkably increased in the last decades due to a great number of different source; industrial, commercial, agricultural, and domestic waste, effluents and emissions as well as hazardous substances. The majority of environmental pollutants are threatening initially human and environmental health but also the integrity and function of ecosystems [1]. In fact, aquatic pollution became a worldwide problem where many waterways are being polluted with organic and inorganic compounds such as pesticides and heavy metals from various sources as industries and mining activities; but heavy metals, unlike organic pollutants, cannot be detoxified via degradation and thus they persist in the ecosystem [2-5]. Aquatic environments particularly coastal areas are characterized by sensitivity to various inorganic and organic pollutants. Globally, accepted procedures for environmental / ecological impact and risk assessment have been attributed to anthropogenic activities and impact on coastal environments. Many chemical contaminants, including organochlorine compounds, herbicides, petroleum products and heavy metals are now recognized to have adverse effects on ocean environments, even when released at low levels. Little attention had been given to this problem until shortly before the 19th century. Metal 
pollution may damage marine organisms at the cellular level and possibly affect the ecological balance. Exposure and ingestion of polluted marine organisms as sea foods can cause health problems in people and animals including neurological and reproductive problems [6]. Heavy metals are natural trace components of the aquatic environment, but their levels have increased due to industrial, agricultural and mining activities. As a result, aquatic animals are exposed to elevated levels of heavy metals. The levels of metals in upper members of the food web like fish can reach values many times higher than those found in aquatic environments or in sediments [7]. There are different routes for metal uptake; this process depends on the ecology, biology and behavior of organisms and species. A biomonitor is an organism that can give information about the concentration of the contaminant in the environment [812]. Several rules for selection of the appropriate biomonitors should be considered. The selected organism should have the ability to detoxify the contaminant turning it into non-harmful compound and should store them several folds of the inhabitant water or sediments. Also, stored contaminant should not affect the healthy status of organism. The selected organism should have a life cycle of at least on year to allow the following of contaminant concentration within its tissue throughout different seasons. It should be of big size to allow analysis of soft tissue to determine the concentration of different contaminants.

\section{Materials and Methods}

\subsection{Study Area and Sampling Protocol}

Two sites were chosen to cover the purpose of the current work. The first one was the Marine Biological Station (MBS), and the second site was the Fishing Port at Sakala (FPS). Both sites (Figure 1) are located on the Red Sea coast at Hurghada city (Red Sea governorate). For detailed study, sampling was carried out for polychaete and water samples, from two main sites during a period of one year; from winter 2006 until autumn 2007. Worms were picked from sediments by hand and rinsed with freshwater to remove sand and debris. For metal analysis, worms were kept in freezer after transported to lab in ice bags. Also water samples were taken in polyethylene acid washed bottles, and then acidified with drops of pure nitric acid.

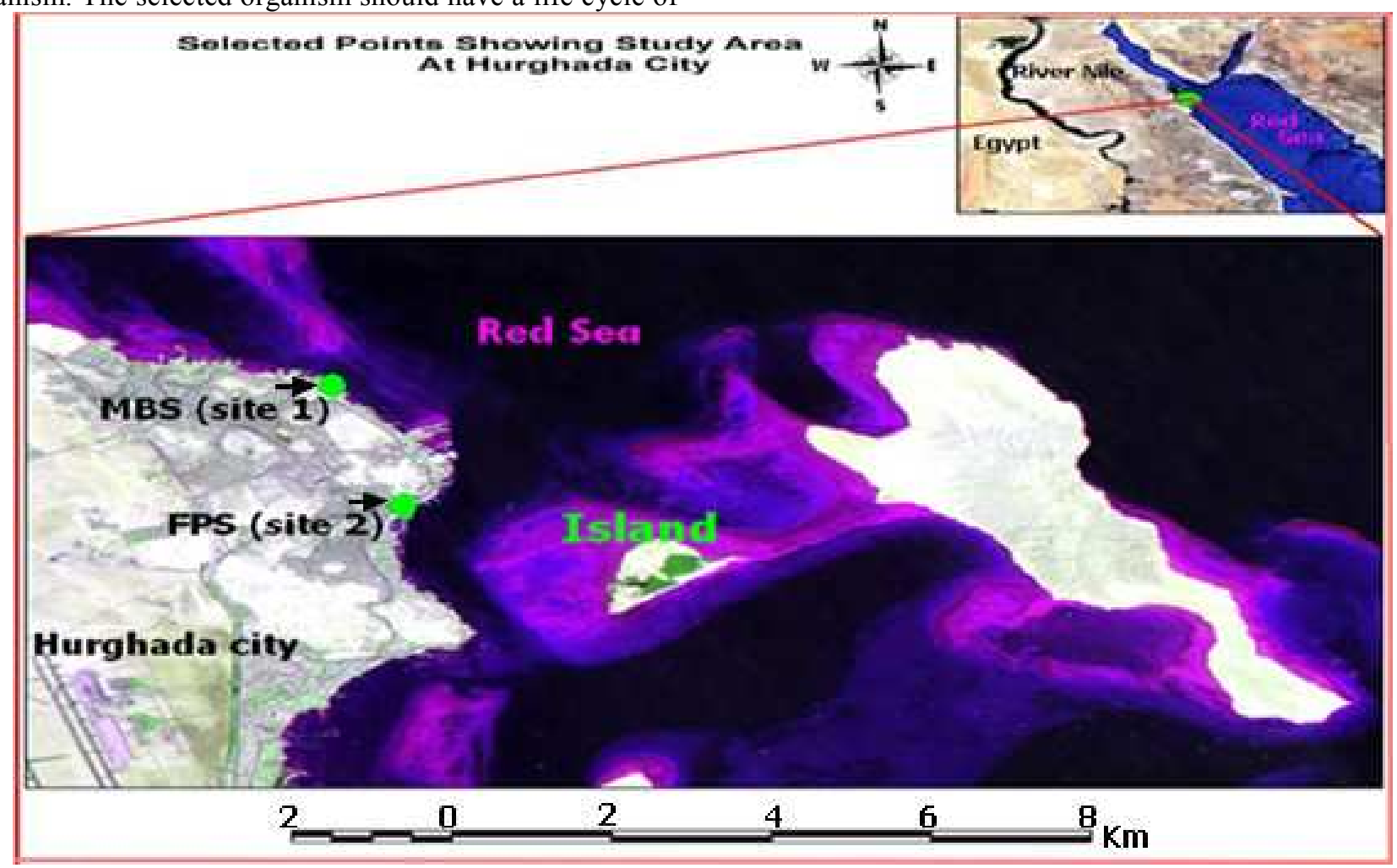

Figure 1. Area of study, Site 1; Marine Biological Station (MBS), site 2; The Fishing Port at Sakala (FPS).

\subsection{Measurement of Ecological Factors}

Some parameters were measured at the field directly. At the two main sites, seasonal measurements of water temperatures, hydrogen ion concentration $\mathrm{pH}$, dissolved oxygen $\mathrm{O} 2$, water electric conductivity, salinity and turbidity, were carried out in the field by using Water, Quality Checker type U-10 code: 10040801000 F6. These measurements were carried out three times for each parameter.

\subsection{Determination of Heavy Metals}

\subsubsection{In Water}

The concentrations of four heavy metals were seasonally determined; Lead $(\mathrm{Pb})$, Cadmium $(\mathrm{Cd})$, Copper $(\mathrm{Cu})$ and Manganese (Mn), according to the methods of [13, 14]. 


\subsubsection{In Tissues}

Stored animals samples were prepared for metal analysis according to $[11,15]$. The whole tissue of Nereis was taken for analysis. Prior to the analysis, the specimens were thawed, rinsed, and weighed. Special care was taken to eliminate sediment particles adhering to the animals. Digestion was performed with analar nitric acid in a water bath till complete digestion. $5 \mathrm{ml}$ conc. nitric acid was added to each tissue sample of the frozen tissue. The tissue was then heated gently in water bath till boiling and vortexed to help the tissue solubilization. The dissolved tissue was cooled at room temperature and additional $0.25 \mathrm{ml}$ of the concentrated nitric acid was added. Then, the solution was heated until it starts to turn brown. The solubilized tissue was cooled. A third addition of $0.1 \mathrm{ml}$ nitric acid was done and the volume was reduced to approximately $0.5 \mathrm{ml}$. The addition of $0.1 \mathrm{ml}$ concentrated nitric acid was repeated until the solution turns clear. The digested tissue was diluted with bidistilled water to $10 \mathrm{ml}$ and analyzed for heavy metals determination using the graphite furnace. Heavy metals were determined by a Perkin-Elmer spectrometer with a specifichollow cathode lamp for each metal. The metal concentration was calculated according to $[15,16]$. The metal concentration was calculated in $\mu \mathrm{g} / \mathrm{g}$ wet weight for tissue and $\mu \mathrm{g} / 1$ for water as follows:

Tissue concentration of metals

$$
=\frac{\text { Reading } \times \text { dilution }}{\text { Weight }(g)}
$$

Bioaccumulation factor (BAF)

Bioaccumulation factor BAF was calculated according to [11] according to the formula

$$
\mathrm{BAF}=\frac{{ }^{*} \text { H.M.C.in soft tissue }}{\text { H.M.C.in inhabiting water }}
$$

*Heavy metal concentration

\subsection{Statistical Analysis}

Analysis of variance on SPSS software package program (Version 17) was used to test the current data. In the case of significant differences, the Multiple Range Comparisons (Least Significant Difference; LSD) was selected from Post Hoc window on the same statistical package to detect the significant difference between means. Also, Pearson correlation coefficients were applied in the present data to compare the effects of Physico-chemical parameters on the concentration of heavy metals in water and tissue and the bioaccumulation factors. Probability values $\leq 0.05$ were defined as significant throughout the current work. However, the values $>0.05$ were considered non-significant. Probability values between 0.05 and 0.01 (both are included) were evaluated as significant. Statistically non-significant, significant and highly significant outputs were accompanied by symbols ${ }^{\mathrm{NS}}$, a ${ }^{\text {and }}{ }^{\text {aa }}$ respectively.

\section{Results and Discussion}

In the present work, the two investigated sites are differed in their nature. The $1^{\text {st }}$ site was subjected to protection by the environment affairs agency, and hence it could be considered as more protected compared to the $2^{\text {nd }}$ one. This site, namely, the fishing port at Sakala region is impacted by several activities of fishing. All the investigated annelid polychaetes worms belong to family nereidae and represented the same specie Nereis succinea. The difference between the two sites in some morphological characters of their studied polychaete Nereis such as width, size or weight is not evidence and don't confirm that the studied samples are different two species. This in fact may be attributed to the difference between the two sites in nutritive state, eutrophication levels and may also be due to ecological factors affecting the physiological status of the animals. The biological activities of the same specie polychaete, for example Nereis divirsicolor was differed significantly from clean to polluted habitats [17]. They [17] explained these differences by the different characteristics of the two sites. On the other hand disturbed environments tend to be characterized by small reselected species [18].

\subsection{Physico-chemical Parameters}

The investigated parameters of water quality were presented in (Table 1) as mean \pm SD. In site 1 (Table 1), the water temperature was seasonally fluctuated from $\left(17.23 \pm 32^{\circ} \mathrm{C}\right)$ in winter to $\left(26.83 \pm 0.56^{\circ} \mathrm{C}\right)$ in summer with annual mean of $\left(22.75 \pm 4.26^{\circ} \mathrm{C}\right)$; while at site 2 temperature was $\left(28.13 \pm 0.15^{\circ} \mathrm{C}\right)$ in summer with mean $\left(23.58 \pm 4.06^{\circ} \mathrm{C}\right)$. There was a clear slight temperature increase from site (1) to site (2) in the summer and a reverse trend during the winter with significance level $(p<0.01)$ between the four seasons except in the case of summer and autumn, which was insignificant at site 1 . These results are in agreement with [19, 20] and lower than data recorded by [21] who found that in the central Red Sea, the water temperature was fluctuated from $\left(22.8^{\circ} \mathrm{C}\right)$ in winter to $\left(31.5^{\circ} \mathrm{C}\right)$ in summer and [22] who reported that the water temperature reported that the water temperature value increased from $\left(27.8^{\circ} \mathrm{C}\right)$ to $\left(31.7^{\circ} \mathrm{C}\right)$ at five stations from the Red Sea coast in Jeddah. Water acidity is known to influence the solubility, availability and toxicity of metals in the aquatic ecosystems [23]. In the present investigation, the level of hydrogen ion $(\mathrm{pH})$ in water at site (1) increased from $(7.53 \pm 0.47)$ in summer to a similar pattern of $(8.13 \pm 0.11)$ in winter and spring and $(8.16 \pm 0.05)$ in autumn with mean annual value of $(7.99 \pm 0.35)$ with significance level $(\mathrm{p}<0.01)$ between summer and autumn, while at site (2) the $\mathrm{pH}$ of water showed a fairly stable pattern with total annual mean $(8.25 \pm 0.25)$ with $(\mathrm{p}<0.01)$ in winter and any other season. The mean seasonal variation of dissolved oxygen recorded in the present study displayed similar pattern at the two sites. It fluctuated from $5.63 \pm 0.11$ to $6.30 \pm 0.26 \mathrm{mg} / \mathrm{l}$ from autumn to spring at site (1) and from $5.10 \pm 0.10$ to $6.06 \pm 0.11 \mathrm{mg} / \mathrm{l}$ from winter to spring at site (2). These records are in accordance with some measurements carried 
out within the Red Sea e.g. [24]. On the other hand, [22] recorded lower values of dissolved oxygen from Saudi Arabia coast ranged from $(5.80-5.83 \mathrm{mg} / \mathrm{l})$. This variation in concentration of dissolved oxygen is attributed to the effect of decomposition of organic matter [25]. Moreover, the second site in the present work received wastewater from different sources leading to the agitation of sea water, hence increasing its content of oxygen.

Nearly, all water parameter scored from site were deteriorated compared to site 1 . For example, the mean of $\mathrm{pH}(8.25 \pm 0.25)$, dissolved oxygen $(5.71 \pm 0.43)$ and turbidity $(12.19 \pm 3.25)$ have deviated from the standard values, while in site 1 these values are in accordance with known values; $\mathrm{pH}(7.99 \pm 0.35)$, dissolved oxygen $(6.03 \pm 0.29)$ and turbidity $(7.10 \pm 1.90)$. Site 2 is located closed to the main road and is exposed to many sources and types of pollution. In addition this site receives high discharges of municipal wastes. Domestic runoff contains different types of detergents, wastes of cars repair and backwash of fish sales and cleaning (Personal obtained data). Hydrocarbons are organic substances require high amount of oxygen of decomposition. These organic pollutants come from car repair wastes using benzene solar, oil and gasoline. Consequently, the process of degradation of such compounds lead to depletion of oxygen, thereby increasing chemical oxygen demand. The higher turbidity at site 2 is expected to be high at such circumstances. Detergents contains alkaline contents and affect $\mathrm{pH}$ was in alkaline side. Marine biological station, namely the $1^{\text {st }}$ site is subjected to protection from anthropogenic activates and has more attention from the Egyptian environmental affairs. Accordingly, water variables there are somewhat in save side. [20] Recorded similar data from MBS for site (1) and were not similar to measurements of turbidity observed in site 2. Conductivity is an important property of seawater because it is one measurement commonly used to calculate the salinity of seawater; in addition, it provides more insight into solvent structure [23]. Also the mean value of conductivity in the $2^{\text {nd }}$ site $(63.74 \pm 0.77 \mu \mathrm{s} / \mathrm{cm})$ was higher than the $1^{\text {st }}$ site $(62.91 \pm 0.55 \mu \mathrm{s} / \mathrm{cm})$. Salinity is considered as a characteristic factor of sea water quality, it is an indicator for wastes and pollutants discharge [19]. High salinity might be due to high evaporation, low precipitation and the lack of a major river inflow [26]. [22, 24, 27] scored such values for site 1 . Furthermore, the one way ANOVA (Table 2) has revealed that the means of hydrogen ion, dissolved oxygen, turbidity and conductivity between the two sites exhibited high significant differences $(0.05>\mathrm{p}<0.01)$.

Table 1. Annual means $\pm S D$ of ecological factors at site (1) during the period of investigation.

\begin{tabular}{lllllll}
\hline Site & W. Temp. & pH & O $_{2}$ & Conductivity & Salinity \\
\hline Site 1 & $22.75 \pm 4.26$ & $7.99 \pm 0.35$ & $6.03 \pm 0.29$ & $62.91 \pm 0.55$ & $42.76 \pm 0.33$ \\
Site 2 & $23.58 \pm 4.06$ & $8.25 \pm 0.25$ & $5.71 \pm 0.43$ & $63.74 \pm 0.77$ & $4.10 \pm 1.90$ \\
\hline
\end{tabular}

Table 2. One way ANOVA testing ecological factors between the two sites.

\begin{tabular}{|c|c|c|c|c|c|c|}
\hline Source & & Sum of Squares & df & Mean Square & $\mathbf{F}$ & Sig. \\
\hline \multirow{3}{*}{ Water temperature } & Between groups & 4.084 & 1 & 4.08 & & \\
\hline & Within groups & 381.18 & 4 & 17.32 & 0.23 & 0.63 \\
\hline & Total & 385.27 & 5 & & & \\
\hline \multirow{3}{*}{ Hydrogen ion } & Between groups & 0.400 & 1 & 0.400 & & \\
\hline & Within groups & 2.099 & 4 & 0.095 & 4.19 & 0.05 \\
\hline & Total & 2.500 & 5 & & & \\
\hline \multirow{2}{*}{ Dissolved oxygen } & Between groups & 0.602 & 1 & 0.602 & & \\
\hline & Total & 3.685 & 5 & & & \\
\hline \multirow{3}{*}{ Turbidity } & Between groups & 155.04 & 1 & 155.04 & & \\
\hline & Within groups & 156.13 & 4 & 7.097 & 21.84 & 0.00 \\
\hline & Total & 311.18 & 5 & & & \\
\hline \multirow{3}{*}{ Conductivity } & Between groups & 4.084 & 1 & 4.084 & & \\
\hline & Within groups & 10.026 & 4 & 0.456 & 8.96 & 0.007 \\
\hline & Total & 14.110 & 5 & & & \\
\hline \multirow[t]{2}{*}{ Salinity } & Within groups & 3.729 & 4 & 0.170 & 0.002 & 0.96 \\
\hline & Total & 3.730 & 5 & & & \\
\hline
\end{tabular}

\subsection{Heavy Metals Concentrations in Tissue at the Two Studied Sites}

As well as ecological parameters, the accumulations of heavy metals in tissues of Nereis were higher (Table 3) in the $2^{\text {nd }}$ site than the $1^{\text {st }}$ one. The mean values of manganese $(0.87 \pm 0.56)$, cadmium $(0.85 \pm 0.33)$ and copper
$(0.95 \pm 0.13)$ were more than three folds in the $2^{\text {nd }}$ site when compared with those of the $1^{\text {st }}$ site; $(0.18 \pm 0.02)$, cadmium $(0.26 \pm 0.23)$ and copper $(0.31 \pm 0.34)$. To understand the interaction between metal concentrations in tissues and habitat, some considerations must be considered: First, some metals may be balanced by uptake-excretion regulation mechanism [28].

Second (Bioavailability of metals and factors affecting 
them). The biologically available form of metal is usually the dissolved ionic form, but not all ionic forms pose the same biological hazard. In the present work statistical analysis has indicted the presence of strong relation between metal availability in water and physicochemical parameters. For example, all metals were observed to increase (Table 4) as water turbidity increase, for example in the case of manganese $r=.956, p<0.01$ ), lead $r=.964, p<0.01$ ). On the other hand, the concentrations of heavy metals in tissues were correlated negatively with $\mathrm{pH}$ metallic ions (Table 4). Hydrogen ion $(\mathrm{pH})$ concentration in water was known to play important role in metal bioavailability. If the water is acidic with a low $\mathrm{pH}$, metals are released much more rapidly than when the water is more alkaline and $\mathrm{pH}$ is comparatively high $[29,30]$. In the present work, the available form of all metals was negatively affected by the associated water $\mathrm{pH}$ $(\mathrm{p}<0.01)$.

Table 3. Heavy metal concentrations $(\mu \mathrm{g} / \mathrm{g})$ in tissue of Nereis at the two sites.

\begin{tabular}{lllll}
\hline Site & Mn & Pb & Cd & Cu \\
\hline Site 1 & $0.18 \pm 0.02$ & $0.59 \pm 0.46$ & $0.26 \pm 0.23$ & $0.31 \pm 0.34$ \\
Site 2 & $0.87 \pm 0.56$ & $0.78 \pm 0.67$ & $0.85 \pm 0.33$ & $0.95 \pm 0.13$ \\
\hline
\end{tabular}

Table 4. Correlation between metals concentration in tissues and $\mathrm{pH} \&$ turbidity.

\begin{tabular}{lll}
\hline Variables & $\mathbf{p H}$ & Turbidity \\
\hline & $\mathbf{r}^{\text {Significance }}$ & $\mathbf{r}^{\text {Significance }}$ \\
\hline $\mathrm{Mn}$ & $-.882-^{\text {aa }}$ & $.956^{\text {aa }}$ \\
$\mathrm{Pb}$ & $-.886-^{\text {aa }}$ & $.964^{\text {aa }}$ \\
$\mathrm{Cd}$ & $-.95-^{\text {aa }}$ & $.904^{\text {aa }}$ \\
$\mathrm{Cu}$ & $-.807-^{\text {aa }}$ & $.974^{\text {aa }}$ \\
\hline
\end{tabular}

aa . Correlation is significant at the 0.05 level (2-tailed).

\subsection{Bioaccumulation Factor}

Based on bioaccumulation factor (BAF) data (Table 5), bioaccumulation of heavy metals at soft tissues of the polychaete Nereis inhabiting marine biological station can be arranged as follows:

$\mathrm{Cu} \quad(784.98 \pm 878.58)>\quad \mathrm{Mn} \quad(686.66 \pm 518.16)>\mathrm{Cd}$ $(326.35 \pm 323.1)>\mathrm{Pb}(191.31 \pm 138.85)$ at fishing biological station (FBS) heavy metal bioaccumulation can be ranked as follows; $\mathrm{Cu}(1261.2 \pm 706.05)>\mathrm{Cd}(984.62 \pm 519)>\mathrm{Mn}$ $(686.66 \pm 518.16)>\mathrm{Pb}(191.31 \pm 138.85)$. The highest value of annual mean of BAF at Nereis tissues were recorded for $\mathrm{Cu}(1023.09 \pm 816.55)$, while the lowest $\mathrm{BAF}$ was for $\mathrm{Pb}$ $(162.97 \pm 118.03)$.

Table 5. Mean annual values of bioaccumulation factors for different heavy metals in tissues of Nereis at site (1) and site (2) during the period of study.

\begin{tabular}{llll}
\hline Annual mean & Mn & Pb & Cd \\
\hline Site (1) MBS & $686.66 \pm 518.16$ & $191.31 \pm 138.85$ & $326.35 \pm 323.1$ \\
Site (2) FBS & $607.2 \pm 292.36$ & $134.62 \pm 90$ & $784.98 \pm 878.58$ \\
Mean & $646.93 \pm 413.44$ & $162.97 \pm 118.03$ & $984.62 \pm 519.61$ \\
\hline
\end{tabular}

One way ANOVA (Table 6) for the bioaccumulation factor (BAF) of the four studied heavy metals at soft tissues of the polychaete Nereis inhabiting MBS and FBS showed highly significant increase $(\mathrm{P}<0.01)$ for bioaccumulation factor of chromium and cadmium at fish biological station. Nonsignificant difference was shown for bioaccumulation factor of manganese, iron, lead and copper at the polychaete worm inhabiting two sites.

Table 6. One way ANOVA, showing the significance between BAF at the two sites during the period of study.

\begin{tabular}{|c|c|c|c|c|c|c|}
\hline Source & & Sum of Squares & df & Mean Square & $\mathbf{F}$ & Sig. \\
\hline \multirow{3}{*}{ Manganese BAF } & Between groups & 37881.760 & 1 & 37881.760 & & \\
\hline & Within groups & 3893661.136 & 4 & 176984.597 & 0.214 & 0.648 \\
\hline & Total & 3931542.896 & 5 & & & \\
\hline \multirow{3}{*}{ Lead BAF } & Between groups & 19283.670 & 1 & 19283.670 & & \\
\hline & Within groups & 301178.159 & 4 & 13689.916 & 1.40 & 0.248 \\
\hline & Total & 320461.830 & 5 & & & \\
\hline \multirow{3}{*}{ Cadmium BAF } & Between groups & 2599942.688 & 1 & 2599942.68 & & \\
\hline & Within groups & 4118364.047 & 4 & 187198.366 & 13.88 & 0.001 \\
\hline & Total & 6718306.735 & 5 & & & \\
\hline \multirow{3}{*}{ Copper BAF } & Between groups & 1360741.504 & 1 & 1360741.50 & & \\
\hline & Within groups & 13974694.946 & 4 & 635213.407 & 2.14 & 0.157 \\
\hline & Total & 15335436.450 & 5 & & & \\
\hline
\end{tabular}

\section{Conclusion}

The present results have clarified the ability of the selected polychaete Nereis succinea to uptake metals from their habitat. This biochemical behavior was confirmed when metals distributions in tissues were compared between reference and impacted areas. This study revealed the presence of higher concentration of $\mathrm{Mn}, \mathrm{Pb}, \mathrm{Cd}$ and $\mathrm{Cu}$ in water at FBS than MBS $(\mathrm{P}<0.01)$ and high tissue concentration of $\mathrm{Mn}, \mathrm{Cd}, \mathrm{Pb}$ and $\mathrm{Cu}$ at individuals collected from FBS $(\mathrm{P}<0.01)$. Higher BAF at Nereis tissues were recorded for $\mathrm{Cu}(1023.09 \pm 816.55)$, while the lowest BAF was for $\mathrm{Pb}(162.97 \pm 118.03)$.

\section{References}

[1] Awheda, I.., Ahmed, A. Y., Fahej, M. A. S., Elwahaishi, S. S. \& Smida, F. A. (2015). Fish as bioindicators of heavy metals pollution in marine environments: a review. Indian Iournal of Applied Research, 5. 
[2] Ravera, O. (2001). Monitoring of the aquatic environment by species accumulator of pollutants: a review. Journal of Limnology, 60, 63-78.

[3] Shukor, Y. N., Baharom, A., AbdRahman, F., Abdullah, M. P., Shamaan, N. A., \& Syed, M. A. (2006). Development of a heavy metals enzymatic-based assay using papain. Analytica Chimica Acta. 566, 283-289.

[4] Duruibe, J. O., Ogwuegbu, M. O. C. \& Egwurugwu, J. N. (2007). Heavy metal pollution and human biotoxic effects. International Journal of Physical Science. 2, 112-118.

[5] Torres, M. A., Barros, M. P., Sara, C. G., Campos, E. P. Satish, R. Richardand, T. \& Sayre, P. C. (2008). Biochemical Biomarkers in algae and marine pollution: A review. Ecotoxicology and Environmental Safety. 71

[6] Stanciu G., Mititelu, M. \& Gutaga, S. (2005). Pesticides and heavy metals determination in marine organisms from Black Sea. Chemical Bulletin. 50, 1-2.

[7] Stanchevai, M., Makedonski, L. \& Petrova, E. (2013). Determination of heavy metals $(\mathrm{Pb}, \mathrm{Cd}, \mathrm{As}$ and $\mathrm{Hg})$ in Black Sea Grey Mullet (Mugil cephalus). Bulgarian Journal of Agricultural Science, 19.

[8] Simkiss, K., Taylor, M., \&Mason, A. Z., 1982. Metal detoxification and bioaccumulation in molluscs. Marine Biological Letters 3, 187-201.

[9] Philips, D. J. H. \& Rainbow, P. S. (1993). Biomonitors of Trace Aquatic Contaminants. Elsevier Applied Science.

[10] Rainbow, P. S. \&Philips, D. J. H. (1993). Cosmopolitan biomonitors of trace metals. Marine Pollution Bulletin, 26, 593-601.

[11] AbdAllah, A. T. (2006). Investigations on bioconcentration and toxicity of lead and copper to the freshwater prosobranch Lanistes carinatus, Malacologia, 48 (1), 27-34.

[12] AbdAllah, A. T. (2014). Light structure as biomarker for heavy metal bioaccumulation and toxicity in molluscan gastropod 330-334. In "Microscopy: advances in scientific research and education," A. Méndez-Vilas, Ed.” Formatex Publishers

[13] AbdAllah, A. T. \&Moustafam M. A. (2002). Accumulation of lead and cadmium in the marine prosobranch Nerita saxtilis, chemical analysis, light and electron microscopy. Environmental Pollution.116, 185-191.

[14] Rvera, O., Beone, G. M. Trincherinem P. R. \&Riccardi, N. (2007). Seasonal variations in metal content of two Unio pictorum mancus (Mollusca, Unionidae) populations from two lakes of different trophic state," Journal of limnology. 66 (1), 28-39.

[15] McDaniel, W. (1991). Sample preparation procedure for petrochemical determination of total recoverable elements in biological tissues in "revision 1.0 Environmental monitoring systems laboratory," pp23-29. U. S environmental protection agency.

[16] Kraak, M. H. S., Toussaint, M., Bleekerm A. J. \& Lavy, D. (1993). Metal regulation in two species of freshwater bivalve. In: Dallinger, R., Rainbow, P. S. (Eds.), Ecotoxicology of Metals in Invertebrates," SETAC Special Publication Series. Lewis Publishers, Ann Arbor, London, pp. 175-186.
[17] Durou, C., Smith, B. D., Romeo, M., Raibow, B. S., Mouneyrac, C., Mouloud, M., Gnassia-Barelli, M., Gellit, P., Detuch, B. \& Amiard-Triquet, C. (2007). From biomarkers to population responses in Nereis diversicolor: Assessment of stress in estuarine ecosystems. Ecotoxicology and Environmental Safety. 66, 402-411.

[18] Attrill, M. J., \& Depledge, M. H. (1997). Community and population indicators of ecosystem health: Targeting links between levels of biological organization. Aquatic Toxicology. 38, 183-197.

[19] Emara, A. M. \& Belal, A. A. (2004). Marine fouling in Suez Canal, Egyp. Journal of Aquatic Research. 189-206.

[20] Mahdy, A. A. (2005). Taxonomical and ecological studies on marine zooplankton of the Red Sea, Egypt," M. Sc. Thesis, Fac. Sci., Al-Azhar Univ. Assiut.

[21] Dowidar, N. M., \& Mostafa, H. M. (1983). Phytoplankton biomass and primary production in the south eastern Mediterranean off the Egyptian coast. Rapp. P. -V. Reun. CIESM, 28 (8): 85-88.

[22] Saeed, M. O., Al-Khamis, S. I. Al-Thobaitim E. S., Ozair, G. \& Mohammad, K. (2005). Study on the silt density index problem in the SWCC Jeddah Sea water reverse osmosis plants1. Saline Water Desalination Research Institute. Saline Water Conversion Corporation (SWCC)," P. O. Box 8328, AlJubail 31951, Saudi Arabia.

[23] Rafiu, A. O. D. P. Roelien \& R. Isaac, (2007). Influence of discharged effluent on the quality of surface water utilized for agricultural purposes," African Journal of Biotechnology. 6, 2251-2258.

[24] Obuid-Allah, A. H. A. T., AbdAllah, H. M. Abu-Eldahab, N. S., Abdul-Rahman, A. A. \& Mahdy, A. M. (2055). Impact of heavy metal contamination on seasonal abundance of planktonic copepods inhabiting mangrove area in Safaga, Red Sea, Egypt. Egypt,” Journal of Experimental Biology (Zoo.). 1: 57-66.

[25] Ait Alla, A., Gillet, P., Deutsch, B., Moukrim, A., \& Bergayou, H. (2006). Response of Nereis diversicolor (Polychaeta, Nereidae) populations to reduced wastewater discharge in the polluted estuary of Oued Souss, Bay of Agadir, Morocco. Estuar. Coastal Coast. Shelf Scince. 633-642.

[26] Bower, A. S., Fratantoni, D. M. Johns, W. E. \& Peters, H. (2002). Gulf of Aden eddies and their impact on Red Sea water. Geophysical Research Letters," 29 (21): 20-25, doi: 10.1029/2002GL015342.

[27] Mohamed, Z. A. \& Mesaad, I. (2007). First report on Noctiluca scintillans blooms in the Red Sea off the coasts of Saudi Arabia: consequences of eutrophication. Oceanologica, 49, 337-351.

[28] Rainbow, P. S. (2002). Trace metal accumulation in marine invertebrate: Marine biology or marine chemistry?. Journal of Marine Biology. Association. U. K., 77: 195-210.

[29] Tayab, M. R, 1991. Environmental impact of heavy metal pollution in natural aquatic systems. Environmental pollution science, $\mathrm{PhD}$ Thesis. pp171. The University of west London.

[30] Wang, A. S., Angle, J. S. Chaney, R. L. Delorme, T. A. \& Reeves, R. D. (2006). Soil pH effects on uptake of Cd and $\mathrm{Zn}$ by Thlaspi caerulescens. Plant and Soil, 281, 325-337. 